\title{
TO CARRY THE UNIVERSE IN ONE'S OWN POCKET: A MINIATURE MITHRAIC RELIEF FROM THE ARCHAEOLOGICAL MUSEUM IN SPLIT
}

\begin{abstract}
Summary: A miniature relief representing the scene of tauroctony, i.e. Mithras killing the bull, is on display in the Archaeological Museum in Split. Despite its visibility, the relief has so far remained unpublished. It is therefore the aim of this article to provide the detailed description of the object, and to contextualize it within the broader framework of "small and miniature reproductions of the Mithraic icon". Based on this, the original provenance and dating of the miniature relief are proposed. Furthermore, the relief is taken as a fine example of interconnectedness of social, material, and religious mobility in "globalizing Roman world". The final part of the article discusses the psychological effectiveness of miniature Mithraic reliefs, suggesting their possible role as memory aids.
\end{abstract}

Key words: small and miniature Mithraic reliefs, tauroctony, Mithras, Salona, Dalmatia, social networks, religious mobility, power of the images

\section{INTRODUCTION}

In one of the glass cases in the Archaeological Museum of Split, among the objects expressing the religious life in the Roman province of Dalmatia, a miniature Mithraic relief is displayed (fig. 1). ${ }^{1}$ Despite its visibility and exposure to the museum visitors,

\footnotetext{
${ }^{1}$ The current text is a result of a research conducted for my MA Thesis "Soli Deo Stellam et Frvctiferam: The Art of the Mithraic Cult in Salona," defended in June 2014 at the Medieval Studies Department at Central European University, under the supervision of Prof. Volker Menze. The expanded version of the text was presented in June 16, 2016 at the international conference on "The Mysteries of Mithras and Other Mystic Cults in the Roman World" in Tarquinia, Italy. Although slightly modified, the current text has retained its main arguments. I would like to express my gratitude to the organizing committee of the conference, Patricia A. Johnston, Attilio Mastrocinque, and László Takács, as well as to the organizers of the panel "The Mysteries of Mithras in the Danubian Provinces", Levente Nagy, Ádám Szabó, and Csaba Szabó for giving me the opportunity to present my paper. I would also like to thank to the participants whose useful comments helped shape this article.
} 


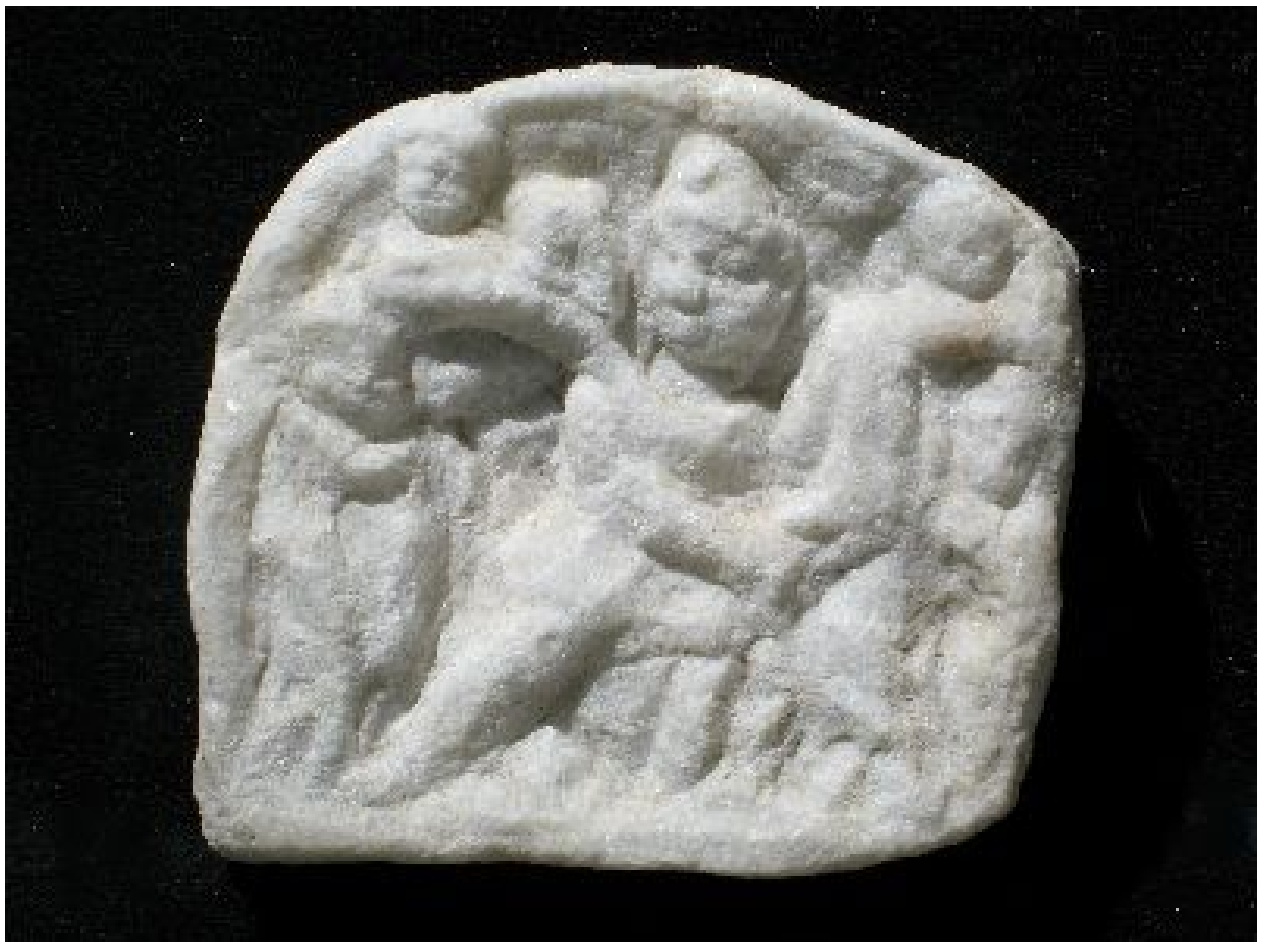

Fig. 1. Miniature Mithraic relief from the Archaeological Museum of Split (photo courtesy of Archaeological Museum of Split)

the relief has managed to escape the attention of scholars and has so far remained unpublished. ${ }^{2}$ There are several reasons why this seemingly inconspicuous object has been overlooked both in Croatian, as well as in international historiography. The relief does not stand out from the surrounding small reliefs and bronze plaques and statuettes exhibited in the glass case due to the fact that they all belong to the same group of objects: the so-called "minor" or "small" archaeological finds. ${ }^{3}$ The importance of such finds for the Mithraic studies has only been recently recognized, due to the conference which dealt with evidence of the small finds in Roman Mithraism, held in Tienen (Belgium) in 2001. ${ }^{4}$ In the introduction of the conference proceedings, Richard Gordon has rightly emphasized how the majority of such finds would have most probably been

${ }^{2}$ I would like to express my gratitude to Zrinka Buljević, museum advisor, for granting me permission to publish this relief, and for providing me with the necessary information and with the photograph of the relief. The relief is recorded under the catalogue entry D-615.

${ }^{3}$ Small archaeological finds include miscellaneous objects of everyday life, like coarse-wares, brooches, figurines, needles, archaeofloral and archaeofaunal material, ecofacts, etc. For the most recent study in small finds and their value for the study of religious practices and social identities, see HoSS, ST. Whitmore, A. (eds): Small Finds and Ancient Social Practices in the Northwest Provinces of the Roman Empire. Oxford-Philadelphia 2016.

${ }^{4}$ Martens, M. - DE BoE, G. (eds): Roman Mithraism. The Evidence of Small Finds. Brussels 2004. 
discarded in the past, as archaeologists have mainly focused on the major works of art and inscriptions. ${ }^{5}$ The same tendency is discernible in Croatian scholarship, where there is hardly any mention of small finds in connection with Mithraic sites. ${ }^{6}$ Furthermore, the lack of interest in small finds is a symptom of the scholarly trend concentrating on deciphering the iconography and subsequently the theology of the cult, as well as of the everlasting quest for its origins. ${ }^{7}$ With the recent acknowledgment of the importance of religious practice and ritual actions, and the attention being drawn to the everyday experiences and practices, objects like our miniature Mithraic relief are finally examined to their full potential. ${ }^{8}$ The first part of this article describes the miniature relief from Split and contextualizes it in terms of its possible place of finding and original provenance. Consequently, the second part deals with the dynamics of road/social networks and regional interactions as factors facilitating the flow of objects (like the miniature relief in question), people, and religious ideas. The third part of the article takes the larger class of 'small and miniature reproductions of the Mithraic icon', and connects their specific mode of representation to the psychological effectiveness of those reliefs, and the responses they evoked at their viewers. Finally, stemming from the previous discussion, the role of the miniature reliefs is considered.

\section{MINIATURE MITHRAIC RELIEF FROM SPLIT}

The relief is executed in marble and it measures only $8.3 \times 7.5 \mathrm{~cm}$. It is of almost perfect square shape, except for the upper semicircular frame. The relief is framed with

${ }^{5}$ GORDON, R.: Introduction. In Roman Mithraism (n. 4) 7; E. SAUER also warns about the symptomatic lack of interest in studying the less "perfect" works of art, on the dipense of the Classical art and architecture, in The Archaeology of Religious Hatred in the Roman and Early Medieval World. Stroud 2005,18 .

${ }^{6}$ One of the exceptions are the excavations of Mithraeum in Konjic, conducted and published by K. Patsch. The author provided a detailed account of all small finds, including their drawings (PATSCH, K.: Mithraeum u Konjicu. Glasnik Zemaljskog muzeja u Sarajevu 4 [1897] 629-656; PATSCH, K.: Archäologisch-epigraphische Untersuchungen zur Geschichte der Römischen Provinz Dalmatien III. Wissenschaftliche Mitteilungen aus Bosnien und der Herzegowina [1899] 186-211). The valuable small finds from another major Mithraeum in the Roman province of Dalmatia, the one in Jajce, were stolen before the discovery was reported to the authorities. Recently, one of those finds, a bronze askos, reappeared as part of a provate collection, and was published by DOMIĆ KUNIĆ, A: Askos iz mitreja u Jajcu (uz poseban osvrt na mitraizam kao imitaciju kršćanstva) [An Askos from Mithraeum in Jajce (with Special Reference to Mithraism as an Imitation of Christianity)]. Arheološki radovi i rasprave 13 (2001) 39-102. D. SERGEJEVSKI, who later excavated and published the Mithraeum, managed to collect a certain number of small finds which included some coins, a brooch, and two lamps (Das Mithräum von Jajce. GZM 49.1 [1937] 11-18).

${ }^{7}$ A survey of Mithraic scholarship is offered by BECK, R.: Mithraism Since Franz Cumont. $A N R W$ II 17.4 (1984) 2002-2115; CHALUPA, A.: Paradigm Lost, Paradigm Found? Larger Theoretical Assumptions Behind Roger Beck's 'The Religion of the Mithras Cult in the Roman Empire'. Pantheon 7.1 (2012) 5-8; MASTROCINQUE, A.: Note panoramique sur les mysterès de Mithra après Cumont. In CuMONT, Fr.: Les mysterès de Mithra [Bibliotheca Cumontiana. Scripta Maiora III]. Ed. N. BELAYCHE A. MASTROCINQUE. Brussels 2013, 59-89.

${ }^{8}$ RAJA, R. - RÜPKE, J.: Archaeology of Religion, Material Religion, and the Ancient World. In RAJA, R. - RÜPKE, J. (eds): A Companion to the Archaeology of Religion in the Ancient World. Malden, MA 2015, 1-26. 


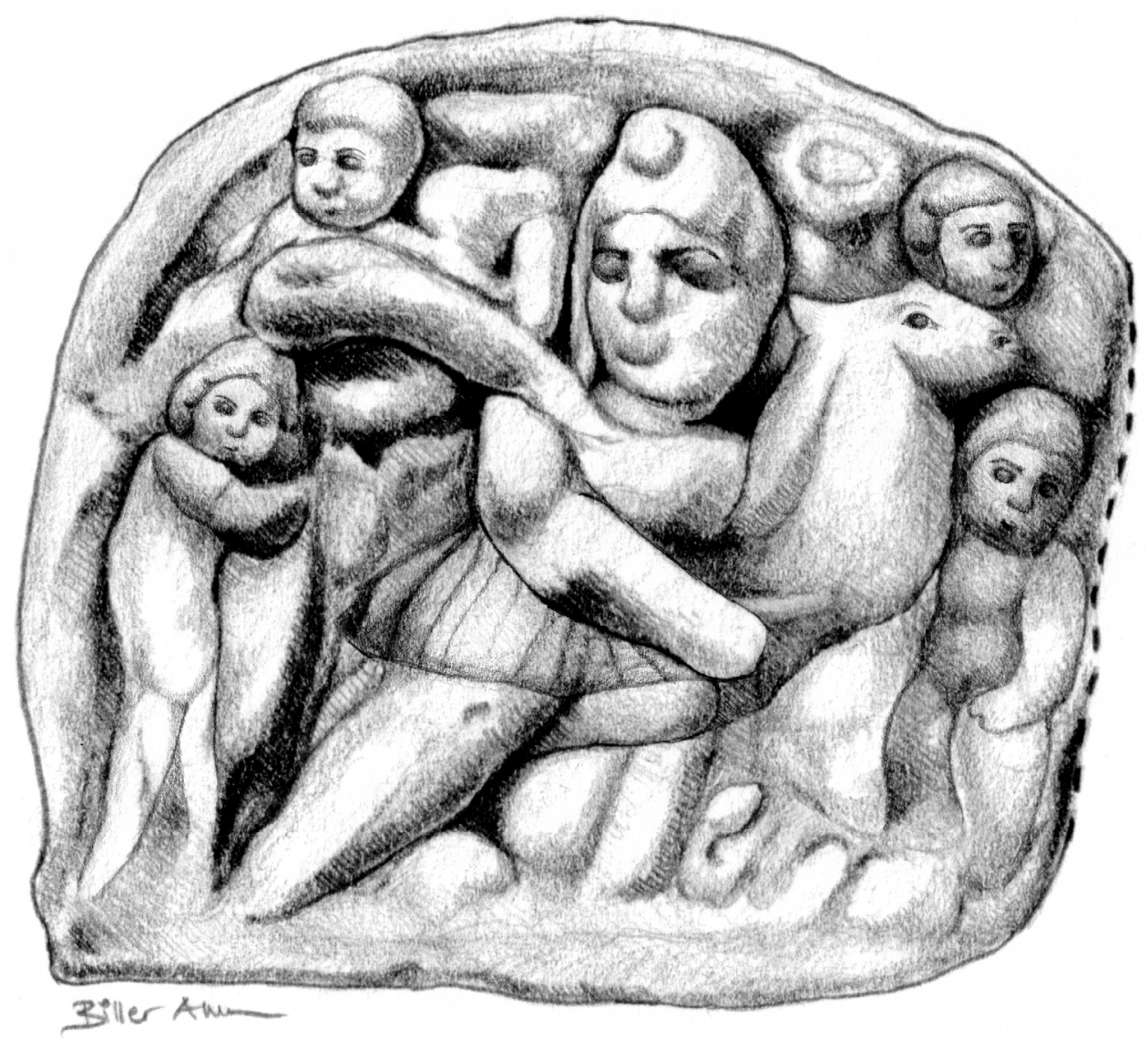

Fig. 2. Drawing after the relief from Split

(Courtesy of Anna Zsófia Biller, Budapest History Museum - Aquincum Museum)

a narrow border, save the right side of the relief which is slightly damaged and worn out. The central field is occupied by the standard scene of tauroctony. Although humble in its execution, the main protagonists can be recognized with more or less certainty (fig. 2). Mithras, dressed in a tunic and wearing a Phrygian cap, is shown stabbing the bull. With his left hand he holds the bull's head, while his right hand, holding a knife, is placed on bull's neck. ${ }^{9}$ He turns his head over his shoulder towards the poorly

${ }^{9}$ It is not clearly recognizable whether he holds the bull's nostrils (as in the majority of the compositions), or he grabs him beneath his mouth (as for example on VERMASEREN, M. J.: Corpus inscriptionum et monumentorum religionis Mithriacae [CIMRM]. Vol I-II. Den Haag 1956-1960, 230 from Ostia, CIMRM 548 from Rome, CIMRM 662 from Asciano), both of which seem less likely, as the bull's head remains in its natural horizontal position, and it is not pulled backwards. The other possibility is that Mithras grabs the bull's horns (CIMRM 204 from Antium, CIMRM 352 from Rome), to which the position of his hand (parallel to the bull's upright neck) would fit. Due to the bad state of preservation it cannot be established with certitude. 
defined protuberance on his fluttering cloak, in which, by analogy to other tauroctonies, we can perhaps recognize a raven. In the upper corners, the busts of Sol and Luna are placed directing their gazes to the left and right, respectively. Torchbearers flank Mithras and the bull. Cautopates stands on the left side holding an inverted torch. His legs are not crossed as usual, but he is shown in semi-profile, with his right leg in front of the left one. ${ }^{10}$ The figure of his counterpart, Cautes, although badly worn out, can be recognized on the right side (his torch is not visible anymore). Of the three animals usually found at the bottom of the composition, none can be identified with certainty due to the worn out state of the relief. However, a snake's head can be possibly recognized at the bottom of the composition, striving towards the bull's wound.

The craftsmanship of the relief is of mediocre quality, where the elements of the tauroctony were given summary treatment, and further clumsiness can be noticed in the neglect of the mutual proportions of the figures depicted. Mithras appears to be the same size as the bull, with his head particularly overemphasized, as if there was a particular attempt to focus on the two main characters of the composition. ${ }^{11}$

Although described in the Museum catalogue entry as of "uncertain provenance", it seems probable that the relief must have been found either in Salona (today Solin, situated in the immediate vicinity of the town of Split), once a capital city of the Roman province of Dalmatia, or in its close proximity, in the so-called ager Salonitanus. ${ }^{12}$ During the past two centuries, archaeological excavations in and around the ancient town of Salona have resulted in a significant number of Mithraic monuments, discovered both intra and extra muros. Altogether fifteen bas-reliefs (some preserved in their entirety, while others only in fragments), and seven votive inscriptions have been discovered so far, which is the largest concentration of Mithraic monuments in the province. ${ }^{13}$ Some of the reliefs are outstanding examples of craftsmanship (e.g. CIMRM 1868, CIMRM 1869), while some have original iconographic solutions (e.g. CIMRM 1861, CIMRM 1879). ${ }^{14}$ It has been suggested that Salona should be regarded

${ }^{10}$ Besides with crossed legs, torchbearers can be shown standing in profile/semi-profile with their legs paralell to each other (CIMRM 1879, which resembles our relief in a posture of hands holding a torch, $2237,2264,2000,2051,2187)$. They can be also shown while standing frontally with parallel legs (CIMRM 1893, 1907, 1910).

${ }_{11}^{11}$ More about this point in the second part of the article.

12 Ager Salonitanus spread from the ancient town of Tragurium (today Trogir) in the west, to the Epetium (today Stobreč) in the east. On the geographical position of the city, see MARIN, E.: Starokršćanska Salona: studije o genezi, profilu i transformaciji grada [Early Christian Salona: Studies on Genesis, Profile and Transformation of the City]. Zagreb 1988, 9-12; Salona Christiana. Ed. E. MARIN. Split 1994, 16-17.

${ }^{13}$ FR. BULIĆ was among the first archaeologists to publish Mithraic monuments from Salona (Iscrizioni inedite. Bulletino di archaeologia e storia dalmata 7 [1884] 132-133; Quattro bassorilievi di Mitra di Salona. BASD 32 [1909] 50-57; Due frammenti di bassorilievo di Mitra nel Museo di Spalato. BASD 35 [1912] 57-58). Interestingly, despite the high number of Mithraic monuments in Salona there have been no comprehensive studies dedicated to it until recently, see SiLnOVIĆ (n. 1); SiLnOVić, N.: Soli Deo Stellam et Frvctiferam: The Art of the Mithraic Cult in Salona. Annual of Medieval Studies 21 (2015) 103-116.

${ }^{14}$ A fragment showing the bull's head and Mithras hand (CIMRM 1868) has been called as "one of the most beautiful examples of ancient art in Dalmatia", by GABRIČEVIĆ, B.: Iconographie de Mithra tauroctone danas la province romaine de Dalmatie. Archaeologia Iugoslavica 1 (1954) 38; on the remarkable 
as a center of the Mithraic cult on the Eastern Adriatic coast, and moreover, a production center of Mithraic reliefs, with several of them having distinctive and unique "Salonitan features". 15

As it is the case with the miniature relief, Mithraic monuments from Salona have either an uncertain place of discovery, or, in the case where the exact or at least an approximate place of their finding is known, none of them was found in situ, but instead in the place of their secondary usage. ${ }^{16}$ Ejnar Dyggve, a Danish archaeologist who conducted excavations in Salona from 1920s to the 1960s, was of the opinion that there were altogether five mithraea dispersed both intra and extra muros, although none of them has been archaeologically proven so far. ${ }^{17}$ The insufficient archaeological context certainly imposes important limitations to the study of the Mithraic cult in Salona. Nevertheless, considering the number of the surviving Mithraic reliefs, and according to the reconstructed dimensions of some of them, it can be concluded that there must have been several mithraea in Salona. ${ }^{18}$

Given the above-mentioned facts, it is easy to assume that the miniature relief from the Archaeological museum of Split was found either in Salona or its environs. The question of the original provenance of this "pocket-sized" relief remains. In order to answer this question, it is necessary to briefly address the broader category of miniature Mithraic reliefs.

\section{OBJECTS IN MOTION - RELIGIONS IN MOTION}

On the occasion of the previously mentioned conference on small finds in Roman Mithraism, Richard Gordon identified a new class of "small and miniature reproductions

quality and beauty of execution of the fragment showing the bust of Luna (CIMRM 1869), see LIPOVACVRKLJAN, G.: Some Examples of Local Production of Mithraic Reliefs from Roman Dalmatia. In SANADER, M. - RENDIĆ-MIOČEVIĆ, A. (eds): Religija i mit kao poticaj rimskoj provincijalnoj plastici: Akti VIII. međunarodnog kolokvija o problematici rimskog provincijalnog stvaralaštva. Zagreb 2005, 253. On the fragment of a circular relief showing the signs of zodiac (CIMRM 1870), see LIPOVAC-VRKLJAN, G.: Posebnosti tipologije i ikonografije mitrijskih reljefa rimske Dalmacije [Typological and Iconographical Particularities of the Mithraic Reliefs in the Roman Province of Dalmatia]. PhD diss. Zagreb $2001,92$. The most recent interpretation of the Salonitan tondo has been given by SILNOVIĆ, N.: The Iconography of Mithraic Tondo from Salona Revisited. In MITREA. M. (ed.): Tradition and Transformation: Dissent and Consent in the Mediterranean. Proceedings of the $3^{\text {rd }}$ CEMS International Graduate Conference. Kiel 2016, 56-75.

${ }^{15}$ LiPOVAC-VRKLJAN: Posebnosti (n. 14) 87; MiletiĆ, Ž.: Mitraizam u rimskoj provinciji Dalmaciji [Mithraism in the Roman Province of Dalmatia]. PhD diss. Zadar 1996, 13.

${ }^{16}$ CIMRM 1860 - north of necropolis in horto Metrodori; CIMRM 1895 - unknown; CIMRM 1868 unknown; CIMRM 1869 - unknown; relief showing tauroctony - lost; CIMRM 1871 - used as cover of a tomb in Crikvine; CIMRM 1865 - inside perimeter city wall; CIMRM 1870 - shipyard; CIMRM 1862 unknown; CIMRM 1867 - unknown; CIMRM 1864 - unknown; CIMRM 1909 - proximity of the church of St. Marta; CIMRM 1859 - built into the private house; CIMRM 1861 - perimeter city walls.

${ }^{17}$ DygGVe, E.: History of Salonitan Christianity. Oslo 1951, 8; according to Dyggve, one of the mithraea was situated in close proximity of the theater, the other close to the amphitheater, the third in the eastern part of the town, while the remaining two outside the city walls.

${ }^{18}$ CIMRM 1860: 150-180 cm; CIMRM 1866: over $150 \mathrm{~cm}$; CIMRM 1868: $1 \mathrm{~m}$; CIMRM 1869: $1 \mathrm{~m}$; thermae $46 \times 72 \mathrm{~cm}$; CIMRM 1871: $46 \times 73 \times 14 \mathrm{~cm}$. 
of Mithraic icon". ${ }^{19}$ What remains so far the only study dedicated to the "small and miniature reproductions of Mithraic icon", Gordon established three main classes of these objects, depending on their context and function: 1) house-reliefs (small and very small reliefs and statuettes, whose dimensions are less than $0.50 \times 0.45 \mathrm{~m}$ ), 2) images emblems (pottery and various utilitarian objects used in the ritual), 3) images for personal devotional use: a) stone medallions, b) personal ornaments, c) gems as private icons. ${ }^{20}$

It is to the group of miniature medallions that the relief from Split most likely belongs. Only four of them have been discovered so far; all are made of marble (like the relief from Split), they are less than $0.015 \mathrm{~m}$ thick, and are of circular or oval shape. All were designed, according to Gordon, in the lower Danubian area, particularly in Moesia Superior or southern Dacia. ${ }^{21}$ One was found in Dacia (CIMRM 2187; $0.15 \times 0.12 \mathrm{~m})$, the second one in Thracia $(C I M R M 2246 ; 0.13 \times 0.10 \times 0.04 \mathrm{~m})$, the third one in Lentia (today Linz, Austria, CIMRM 1415, diam. $0.15 \mathrm{~m}$ ), while the fourth one comes from Caesarea Maritima in Palestine (diam. $0.075 \mathrm{~m}$ ). Medallions from Dacia and Thracia, as Gordon suggests, probably belonged to the veterans who had their base somewhere along the Danube, while the two latter ones were found as votives in mithraea, presumably dedicated by state officials or military personnel. ${ }^{22}$

Although not necessarily of circular shape, but having a semicircular upper frame instead, the miniature size of the Split relief certainly places it into the group of miniature medallions. Moreover, it is almost the smallest specimen of them: nearly half the size of the Dacia, Thracia, and Lentia one, and comparable in size only to the Caesarea medallion. It seems that it belongs to this group by the place of its origins as well. The shape of the miniature relief from Split, in particular the stylized cave arch, could be compared to another relief in white marble belonging to the class of house reliefs, found in the canabae at Vindobona (today Vienna, CIMRM 1650, $0.23 \times 0.24 \times 0.048 \mathrm{~m}$ ), believed to be brought there from either Dacia or Moesias by an individual soldier or camp-follower (fig. 3) ${ }^{23}$ The Split relief lacks the elaboration of subsidiary scenes, which can be attributed to its miniature size (although the equallysized medallion from Caesarea has the characteristic lower register), and moreover, to the desire to only depict the central act of the myth. ${ }^{24}$

One further question that deserves attention is the identity of the person who brought the relief to Salona. As mentioned earlier in the text, Salona was the capital city of the province, with a favorable geographical location along the central part of the eastern Dalmatian coast. ${ }^{25}$ With five military roads built under governor Publius

${ }^{19}$ GORDON, R.: Small and Miniature Reproductions of Mithraic Icon: Reliefs, Pottery, Ornaments, and Gems. In MARTENS - DE BOE (n. 4) 259-283.

${ }^{20}$ GORDON (n. 19) 263.

${ }^{21}$ GORDON (n. 19) 273.

${ }^{22}$ GORDON (n. 19) 274.

${ }^{23}$ GORDON (n. 19) 266; the upper semicircular frame is characteristic for reliefs from Dacia, Moesia and Thracia, see LIPOVAC-VRKLJAN: Posebnosti (n. 14) 165.

${ }^{24}$ More about this point in the second part of the article.

${ }^{25}$ On the history of the city see RENDIĆ-MIOČEVIĆ, D.: Antička Salona (Salonae): povijesno-urbanistički i spomenički fenomen (S.O.S. za baštinu) [Ancient Salona (Salonae): Historical-urbanistic and Monumental Phenomenon (S.O.S. for Heritage)]. In RENDIĆ-MiOčEVIĆ, D.: Dalmatia Christiana. Opera 


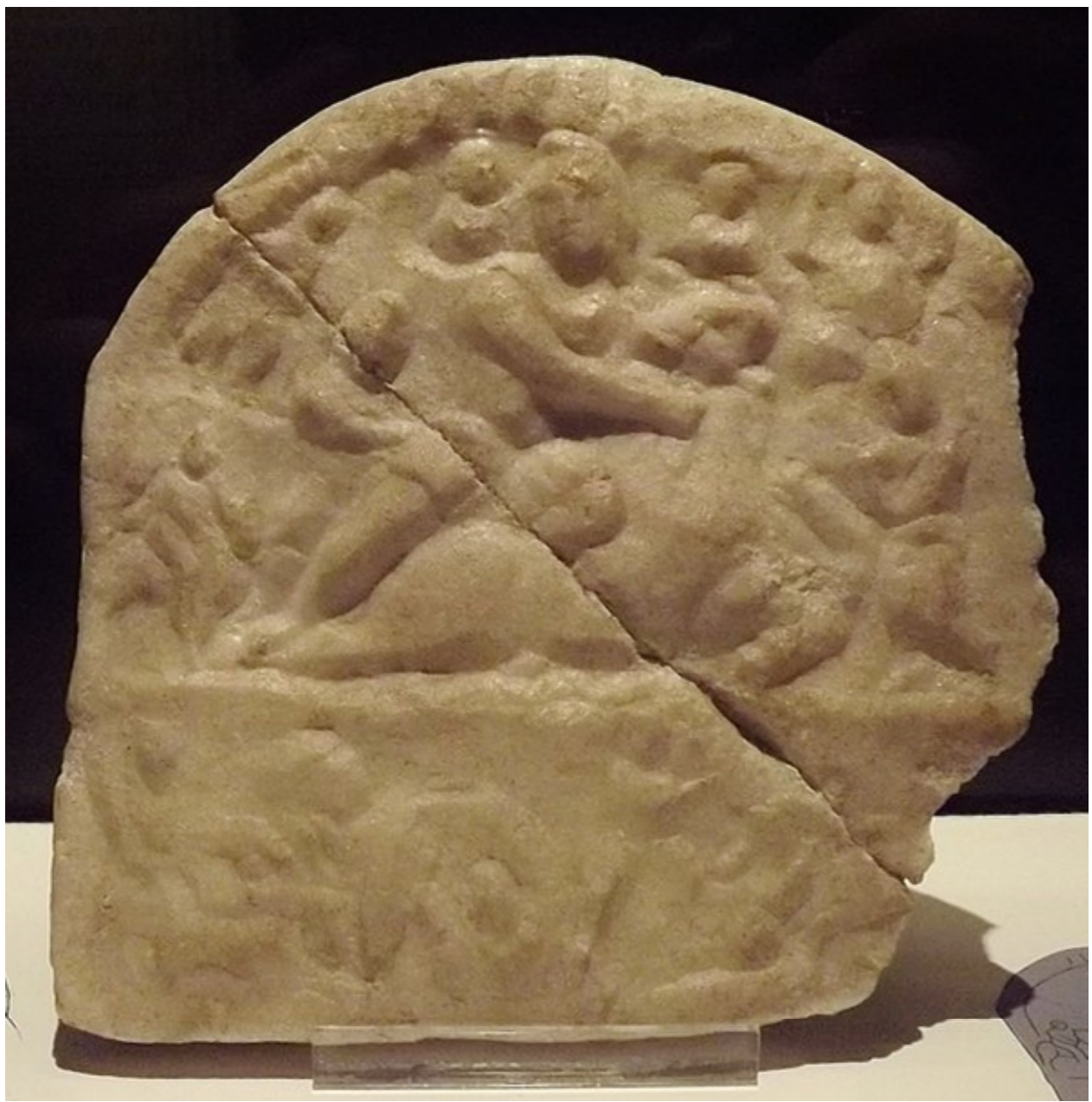

Fig. 3. Miniature marble relief from Vienna

(http://www.tertullian.org/rpearse/mithras/display.php?page=cimrm1650, accessed December 5, 2016)

Cornelius Dolabella (14-20 CE), Salona became caput viae of the province and this strategic position enabled excellent connections with the hinterland of the province and further with Pannonia. ${ }^{26}$ Salona was also a seaport of wide regional economic and military significance. ${ }^{27}$ Along with being the strategic center of the province,

omnia. Ed. N. CAMBI. Zagreb 2011, 329-333; MARIN, E.: Grad Salonae/Salona [The City of Salonae/Salona]. In MARIN, E. (ed.): Longae Salonae. Vol. I. Split 2002, 9-12.

${ }^{26}$ GLAVIČIĆ, M.: Organizacija uprave rimske provincije Dalmacije prema natpisnoj građi [Administrative Organization of the Roman Province of Dalmatia According to Inscriptions]. In ŠEGVIĆ, M. MARKOvić, D. (eds): Klasični Rim na tlu Hrvatske. Arhitektura, urbanizam, skulptura. Zagreb $2014,43$.

${ }^{27}$ MARIN, E.: Moguće pomorske komunikacije starokršćanske Salone [Possible Maritime Connections of Early Christian Salona]. Histria Antiqua 21 (2012) 123-128; BoRzIĆ, I.: Rimske luke - 
Salona was also the main administrative center and the seat of the Roman customs service (publicum portorii Illyrici). ${ }^{28}$ Already Per Beskow emphasized the importance of the customs officials, particularly the slaves of the portorium, in the local spread of the cult of Mithras. ${ }^{29}$ That custom officials were involved in the cult of Mithras in Salona is confirmed by one altar (unfortunately now lost) carrying the inscription mentioning two officials of the customs service: Fortunatus, arcarius, who dedicated the altar to Mithras for the benefit and safety of Pamphilius, dispensator. ${ }^{30}$

To illustrate how the mobility of the customs officials might have affected the spread of the cult, it is worth mentioning two inscriptions from Vratnik, the customs outpost situated in the vicinity of ancient Senia (today Senj). ${ }^{31}$ Senia was the most important port of the northern part of Dalmatia, and part of a major road running from Aquilieia to Dirrahium, and branching further north via Arupium to Siscia and Poetovio. $^{32}$ It became the customs post in the second half of the 2 nd century CE, which is in fact known only from the two Mithraic inscriptions. ${ }^{33}$ The first inscription mentions spelaeum furnished by a servus vilicus named Hermes Fortunatianus (also mentioned on an inscription from the customs post in Atrans, Noricum), ${ }^{34}$ belonging to the conductor C. Antonius Rufus. ${ }^{35}$ The second one was set up by Faustus, servus vilicus of T. Iulius Saturninus, who was both praefecti vehiculorum et conductoris publici portorii. ${ }^{36}$ C. Antonius Rufus and T. Iulius Saturninus (whose presence is also attested in Apulum, Dacia) ${ }^{37}$ are both mentioned on an inscriptions from the Mithraeum I from Poetovio (today Ptuj, Slovenia), the administrative center of the entire publicum portorii Illyrici. $^{38}$

One can easily imagine a similar situation in Salona where, together with the movement of customs personnel, religious ideas and the accompanying easily-trans-

riječne i morske - i pomorstvo na Jadranu [Roman Ports - River and Sea - and Shipping on the Adriatic]. In Klasični Rim (n. 26) 54.

${ }^{28}$ SuIĆ, M.: Antički grad na istočnom Jadranu [Ancient City on the Eastern Adriatic]. Zagreb 2003, 156; WILKeS, JoHN J.: Salona: A Roman Colony and Its People (c. $50 \mathrm{BC}$ - c. AD 150). In Longae Salonae (n. 25) 89.

${ }^{29}$ BESKOW, P.: The Portorium and the Mysteries of Mithras. Journal of Mithraic Studies III.1-2 (1980) $1-18$.

${ }^{30}$ CIL III 1955; CIMRM 1875; Pamphilius and Fortunatus were probably imperial slaves/freedmen belonging to the administrative staff of the financial and custom offices, see SELEM, P. - VILOGORAC BRČIĆ, I.: Religionum Orientalium Monumenta et Inscriptiones Salonitani. Zagreb 2012, 171.

${ }^{31}$ GLAVAŠ, V.: Prometno i strateško značenje prijevoja Vratnik u antici [Traffic and Strategic Importance of the Mountain Pass Vrantik in Antiquity]. Senjski zbornik 37 (2010) 5-18.

${ }^{32}$ On the strategic, economic, and commercial importance of Senia, see GLAVIČIĆ, M.: Značenje Senije tijekom antike [The Importance of Senia during the Antiquity]. Senjski zbornik 21 (1994) 41-58; LJUBOvić, E.: Svjedočanstva o rimskoj Seniji [Testimonies about Ancient Senia]. Senj 2001, 9-14; GLAVIČIĆ, M.: Kultovi antičke Senije [The Cults of Ancient Senia]. Zadar 2013, 1-5, 89-91.

${ }_{33}$ LuUbOVIĆ (n. 32) 37; GLAVIČIĆ: Kultovi (n. 32) 89-102.

${ }^{34}$ CIL III 5117, CIL III 5487.

${ }^{35}$ CIL III 13283; CIMRM 1846.

${ }^{36}$ CIL III 12283; CIMRM 1847.

${ }^{37}$ SzABÓ, CS.: The Cult of Mithras in Apulum: Communities and Individuals. In ZERBINI, L. (ed.): Culti e religiositá nelle provincie Danubiane. Bologna 2015, 413.

${ }^{38}$ CIL III, 14354, 30/CIMRM 1490; CIL III 14354, 29/CIMRM 1493; CIL III 14354, 33/CIMRM 1501; CIL III 4094/CIMRM 1507. 
portable objects, like the miniature relief from Split, were disseminated. Apart from customs officials, it could have been a member of the army with whom the relief might have arrived to Salona. As mentioned earlier in the text, reliefs from Dacia (CIMRM 2187) and Thracia (CIMRM 2246) were presumably owned by the veterans, while the reliefs from Lentia (CIMRM 1415) and Caesarea Maritima could have been deposited as votives by either state officials or military personnel. An inscription from Salona mentions Aurelius, member of the equestrian order, pointing to the fact that members of the army were involved in the cult in Salona as well. ${ }^{39}$

Anna Collar has recently shown how "people's social networks facilitated the spread of ideas" in Roman world, particularly religious movements on both local and global levels. ${ }^{40}$ Indeed, the role of connectivity and networks in a 'globalizing Roman world,' where objects could easily travel long distances (from Dacia to Palestine, as illustrated previously), is important for our understanding of the circulation of material culture and religious ideas. ${ }^{41}$ The interdependence of the major road communications and Mithraic sites in the Roman province of Dalmatia has already been emphasized, indicating the significance of inter-connectivity and networks in the spread of the cult in Dalmatia (fig. 4). ${ }^{42}$

The provenance of the relief in the lower Danubian area is an indicative factor for the approximate dating of the relief. Since the exact spot of finding and the original context of the relief are unknown (and the worn out state does not help either), one can only offer an approximate dating. Namely, the compositional and iconographical influences of the Mithraic reliefs from the Pannonian and Danubian regions

${ }^{39}$ CIL III 8677; CIMRM 1872; SELEM - VILOGORAC BRČIĆ (n. 29) 170-171. The cult of Mithras has traditionally been considered as 'military religion', but as recently demonstrated, besides army it were the members of the customs office who were among the cult's early colporteurs into provinces, see GORDON, R.: Who Worshipped Mithras. Journal of Roman Archaeology 7 (1995) 463; BECK, R.: The Mysteries of Mithras. In Kloppenborg, J. S. - Wilson, S. G. (eds): Voluntary Associations in the Graeco-Roman World. London 1996, 177; BECK, R.: Four Men, Two Sticks, and a Whip: Image and Doctrine in a Mithraic Ritual. In Whitehouse, H. - MARTIN, L. H. (eds): Theorizing Religions Past. Archaeology, History, and Cognition. Walnut Creek 2004, 88; GORDON, R.: Institutionalized Religious Options. In RÜPKE, J. (ed.): A Companion to Roman Religion. Malden, MA 2007): 395; GORDON, R.: The Roman Army and the Cult of Mithras. A Critical Review. In WOLFF, C. - LE BOHEC, Y. (eds): L'armée romaine et la religion sous le haut empire romain. Lyon 2009, 421.

${ }^{40}$ Collar, A.: Religious Networks in the Roman Empire: The Spread of New Ideas. Cambridge 2013, 2-3; the importance of social networks has been already emphasized by BECK: The Mysteries (n. 39); BECK, R.: On Becoming a Mithraist. New Evidence for the Propagation of the Mysteries. In VAAGE, L. E. (ed.): Religious Rivalries in the Early Roman Empire and the Rise of Christianity. Waterloo 2006, $175-194$.

${ }^{41}$ PitTs, M. - Versluys, M. J.: Globalisation and the Roman World: Perspectives and Opportunities. In PITTS, M. - VersluYs, M. J. (eds): Globalisation and the Roman World. World History, Connectivity and Material Culture. Cambridge 2015, 3-31; also on the role of regional and long distance interactions, see AlCOCK, S. E. - EGRI, M. - FrAKES, J. E. (eds): Beyond Boundaries. Connecting Visual Cultures in the Provinces of Ancient Rome. Los Angeles 2016.

42 LipovaC-VRKLJAN: Posebnosti (n. 14) 197; LiPOVAC-VRKLJAN, G.: Mithraic Centers on the Road Communications in Croatia (Parts of Roman Dalmatia, Pannonia Inferior, Pannonia Superior and Histria). The Example of Mursa. In Ptuj v rimskem cesarstvu, mitraizem in njegova doba. Pokrajinski muzej Ptuj, Mednarodno znanstveno srečanje 11.-15. Oktober 1999. Archaeologia Poetovionensis 2. Ptuj 2001, 233-249. 


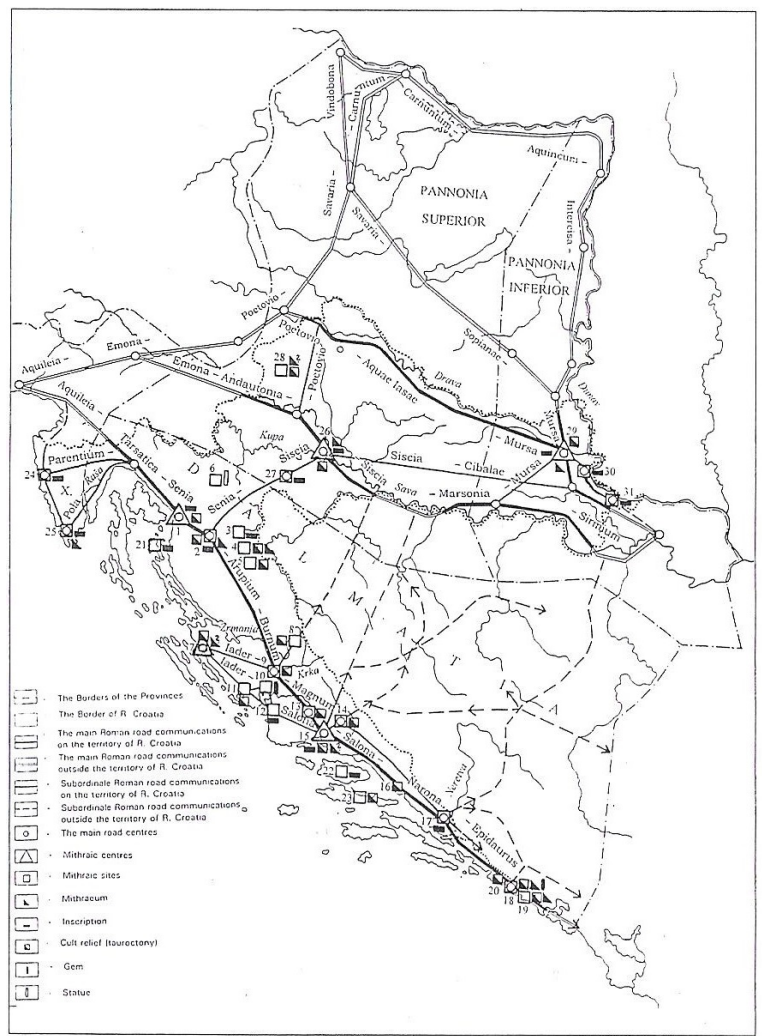

A list of Mithraic sities
1. SENJ/SENIA/
2. Prozor/Arupium/
3. PODUM
4. ČOVIĆI-RAJANOV GRIČ
5. SINAC
6. ČAKOPVAC
7. ZADAR/ADER/
8. KNIN
9. IVOŠEVCI/BURNUM/
10. SKRADIN/SCARDONA/
11. KAŠIĆ
12. DANILO GORNJE/RIDER/
13. UMLJANOVIĆI-BALINA
GLAVICA/MUNICIPIUM MAGNUM/
14. GARDUN/TILURIUM/
15. SOLIN
16. ZASTROG
17. VID-METKOVIČ/NARONA/
18. CAVTAT
19. MOČIĆI
20. LOPUD
21. RAB/ARBA/
22. ŠKRIP -ON InS. BRAČ/BRATTIA/
23. STARIGRAD ON INS HVAR/PHAROS/
24. POREČ/PARENTIUM/
25. PULA/POLA/
26. SISAK/SISCIA/
27. TOPUSKO/AD FINES?
28. PREGRADA
29. OSIJEK/MURSA
30. DALJ/TEUTOBURGIUM/
31. ILOK/CUCCIUM/

Fig. 4. Mithraic Centers on the Road Communications in Dalmatia (Lipovac Vrkljan: Posebnosti [n. 14] 249)

started penetrating Dalmatia in the 3rd century CE, to which we can roughly date the miniature relief from Split. ${ }^{43}$

\section{THE POWER OF MINIATURE RELIEFS}

As noted earlier in the text, the craftsmanship of the miniature relief from Split is of modest quality and shows a particular willingness to concentrate on the two main protagonists of the tauroctony scene, i.e., Mithras and the bull. Moreover, as noted by Gordon, the mediocre and poor quality seems to be the standard for the small and miniature Mithraic reliefs. ${ }^{44}$ Regardless of their low quality, these miniature reliefs

${ }^{43}$ GABRIČEVIĆ, B.: Mitrin kult na području rimske Dalmacije [The Mithras Cult in Roman Dalmatia]. PhD diss. Zagreb 1951, 43-51; GABRIČEVIĆ (n. 14) 37-52; MiLETIĆ, Ž.: Mitraizam u rimskoj provinciji Dalmaciji [Mithraism in the Roman Province of Dalmatia]. PhD diss. Zadar 1996, 18-19; LIPOVAC-VRKLJAN: Posebnosti (n. 14) 144-147.

${ }^{44}$ GORDON (n. 19) 266. 
encapsulate all the necessary elements of the tauroctony, and are even elaborated by further subsidiary scenes placed in the lower register. As they are all made of stone and follow the iconographical scheme of the cult-reliefs, they "allude to and derive their legitimacy from (...) temple relief" ${ }^{45}$ There are several questions raised by such character of the miniature reliefs. First, whether the treatment given to these small objects is intentional, and connected with this, what would be the motivation behind it? Second, how and to what extent was the audience able to recognize what is represented on them? Finally, what was the role of these reliefs?

Members of the cult were able to recognize what is represented on the miniature reliefs because they approached them with particular 'mental sets', i.e., with a particular set of experiences and expectations, which helped them to decipher what is represented on the small reliefs/cryptograms. ${ }^{46} \mathrm{Bal}$ and Bryson have argued that there is a close relationship between reception and particular social groups. ${ }^{47}$ According to them, different groups possess different codes of viewing and members of a particular group acquire their familiarity and learn how to operate with these codes. ${ }^{48}$ The particular form of representation, Gombrich argues, is connected to the "purpose and the requirements of the society in which the given visual language gains currency". ${ }^{49}$ The members of the cult gained familiarity with the sacred narrative and the specific visual codes used to represent it, as they were able to see the large and elaborate cult reliefs in the mithraeum. More importantly, Mithraic ritual imitated the Mithraic cult image. ${ }^{50}$ During the ritual the sacred narrative represented on the cult reliefs was re-enacted, thus making a mithraeum a tableau vivant, and the cult participants contemporaries with the mythic event. ${ }^{51}$ What did the tauroctony scene symbolize, i. e. why was it important that members gain the knowledge about it? According to Beck, ${ }^{52}$ tauroctony represents an organized and coherent symbolic system, a so-called

${ }^{45}$ GORDON (n. 19) 267.

${ }^{46}$ GOMBRICH, E. H.: Art and Illusion. A Study in the Psychology of Pictorial Representation. London 1992, 53.

${ }^{47}$ BAL, M. - BRYSON, N.: Semiotics and Art History. The Art Bulletin 73.2 (1991) 186; A. GELL stressed the importance of "network of relationships surrounding particular artworks in specific interactive setting," and pointed to the fact that besides the "institutional framework of the production and circulation of artworks" one needs to take into the account institutions in a broader sense, like cults (Art and Agency. An Anthropological Theory. Oxford 1998, 8).

${ }^{48}$ BAL-BRYSON (n. 47) 186. Although they claim that the access to the codes varies within the group, one can imagine that the majority of the initates would have gained their knowledge of what the tauroctony represents.

${ }^{49}$ GOMBRICH (n. 46) 78.

${ }^{50}$ ElSNER, J.: Art and the Roman Viewer. The Transformation of Art from the Pagan World to Christianity. Cambridge 1995, 241.

${ }^{51}$ Dirven, L.: The Mithraeum as tableau vivant. A Preliminary Study of Ritual Performance and Emotional Involvement in Ancient Mystery Cults. Religion in the Roman Empire 1 (2015) 20-50.

${ }^{52}$ BECK, G.: A Note on the Scorpion in the Tauroctony. JMS 1 (1976) 208-209; BECK, G.: Cautes and Cautopates: Some Astrological Considerations. JMS 2 (1977) 1-17; BECK, G.: Planetary Gods and Planetary Orders in the Mysteries of Mithras. Leiden 1988; BECK, G.: The Religion of the Mithras Cult in the Roman Empire. Oxford 2006. For a comprehensive overview of the extensive literature on the topic, see CHALUPA (n. 7), with various articles in the same volume offering their responses to Beck's notion of 'star-talk'. 
'star-talk', representing the map of heavens, i.e. a map of soul's celestial journey towards immortality. Mithras played the central role in this process; he is the focus of both the tauroctony scene and of the celestial map, from where he overseas the journey one's soul is making.

Since the members of the cult gained their familiarity with the sacred narrative and the specific visual codes used to represent it, the portable miniature reliefs could have served as a memory aid, an abbreviated image, which they were able to carry with them over long distances, reminding them of their experiences and keeping the sense of identity established within the mithraeum. ${ }^{53}$ In this sense, the miniature reliefs become agents of the social processes established within the mithraeum. ${ }^{54}$ When looking at it, the viewer mobilizes his memory, as Gombrich explains it, as miniature reliefs depict only certain elements of its prototype (cult image), while other elements are, by the power of suggestion, supplemented in the process which he calls projection, triggered by recognition. 55

The degree of effectiveness of an image (the power of the image), and the responses it evokes, is directly related to the form and quality of the image. ${ }^{56}$ These abbreviated images are, according to Freedberg, even more powerful than the fully elaborated ones. The reason is that beholder's emotions intensify, as one becomes aware of the elements that are absent, i.e., they become present in a form of a mental image, evoking the experiences from the mithraeum. ${ }^{57}$ An image possesses "clues to the organic presences registered upon it"; with abundant clues one is able to grasp those presences more directly, but when there are less clues one's mind is more actively involved and triggered to search for it. ${ }^{58}$ The cult images

may attract and guide the imagination more immediately and effectively than mental ones; but if it is their formal qualities that serve as the means of attraction, what guarantee is there that imagination will not remain with the pleasures of sense (...) instead of passing on to the next stages of concentration and reconstitution? (...) What if the lingering is occasioned by color, line, and pleasure in anatomy, and not by reflections of sacred history and dogma? ${ }^{59}$

What was the role of these "powerful" miniature objects? According to Gordon, they served the personal needs of piety and were, due to their convenient size, easily trans-

${ }^{53}$ GoRdon, R.: Trajets de Mithra en Syrie romaine. Topoi 11.1 (2001) 93.

${ }^{54}$ GELL (n. 47) 7, 19; M. J. VERSLUYS talks about objects becoming agents and "functioning in a network of social relationships" (Roman Visual Material Culture as Globalising Koine. In PITTS-VERSLUYS [n. 41] 166).

${ }_{55}$ GOMBRICH (n. 46) 204; the same is argued by Alferd Gell who calls the process "triggering recognition", where "recognition may not occur spontaneously, but once the necessary information has been supplied, the visual recognition cues must be present, or recognition will still not occur", GELL (n. 47) 26. $1989,178$.

${ }^{56}$ FreEDBERG, D.: The Power of Images. Studies in the History and Theory of Response. Chicago

\footnotetext{
${ }^{57}$ FrEEDBERG (n. 56) 178.

${ }^{58}$ FREEDBERG (n. 56) 245.

${ }^{59}$ FREEDBERG (n. 56) 187.
} 
ported over considerable distances; even in the case when they are used as votives (i.e. relief from Caesarea Maritima), Gordon believes that they were originally intended for domestic worship. ${ }^{60}$ Faraone is right to express his doubt about the domestic context for the Mithraic rituals involving the miniature reliefs, and suggests their usage as protective amulets. ${ }^{61}$ Indeed, the fact that they were carried about by the individuals to different parts of the Roman Empire, combined with the cult's salvific concerns, points to their probable amuletic role. ${ }^{62}$ The tendency to focus on depicting the central scene of tauroctony (as stressed earlier in the article) speaks in favour of such an interpretation, as Faraone argues, making "the protective power of this scene (...) always recognizable and therefore always available to individual (...) worshippers." $" 63$

This article began with presenting a seemingly simple small relief from the Archaeological museum of Split, and it ends with the conclusion that this and the related objects had a more complex role than was initially considered. The relief bears witness to a dynamic processes of the movement of religion and material culture in the Roman world. One possessing the miniature relief was constantly reminded of the cosmic connotations of the image, and therefore, was able to wander around the Empire while carrying the universe in one's own pocket. ${ }^{64}$

\author{
Nirvana Silnović \\ Central European University, Budapest \\ Hungary
}

${ }^{60}$ GORDON (n. 19) 263-265.

${ }^{61}$ FARAONE, CHR. A.: The Amuletic Design of the Mithraic Bull-Wounding Scene. JRS 103 (2013) 100; on the magic and the cult of Mithras, see MASTROCINQUE, A.: Studi sul mitraismo: Il mitraismo e la magia. Roma 1998; GORDON (n. 19) 275; AlvAR EzQUERRA, J.: Mithraism and Magic. In GORDON, R. MARCo Simón, F. (eds): Magical Practices in the Latin West. Papers from the International Conference held at the University of Zaragoza, 30 Sept.-1 Oct. 2005. Leiden 2010, 519-549.

${ }^{62}$ On the salvation and the astral interpretation of the tauroctony scene, see BECK, R.: A Note (n. 52); BECK, R.: Cautes (n. 52); BECK, R.: Planetary Gods (n. 52); BECK, R.: In the Place of Lion: Mithras in the Tauroctony. In HINNELLS, J. R. (ed.): Studies in Mithraism: Papers associated with the Mithraic Panel organized on the occasion of the XVIth Congress of the International Association for the History of Religions. Rome 1994, 29-50; the latest review of the state of research and previous scholarship on the topic is offered by BECK, R.: Mithras and the Heavens: First Explorations; Mithras and the Heavens: Quis Ille?; The Astronomical and Astrological Matrix. In Beck on Mithraism. Collected Works with New Essays. Aldershot 2004, 127-231, 235-291, 295-329; BECK, R.: The Religion of the Mithras Cult in the Roman Empire. Oxford 2006.

${ }^{63}$ FARAONE (n. 61) 113.

${ }^{64}$ On the connections between the cosmology and the tauroctony scene, see n. 62. 